\begin{tabular}{lll}
\hline JSM (9) (1) \\
Jttps://journal.unnes.ac.id/sju/index.php/jsm/index
\end{tabular}

\title{
FABER METHOD CLASSICAL PIANO LEARNING IN PURWACARAKA MUSIC SCHOOL PURWOKERTO
}

\author{
Nur Aini Putri Utami \\ Kusrina Widjajantie $^{\bowtie 2}$ \\ Department of Drama, Dance, and Music, Faculty of Languange and Arts, UNNES.
}

\begin{abstract}
Info Artikel
Sejarah Artikel (Diisi oleh

editor)

Diterima :

Disetujui :

Dipublikasikan :

Keywords:

Piano, Faber Method,

Classical Learning

Abstrak

Sekolah Musik Purwacaraka Purwokerto mampu melahirkan siswa piano klasik yang berbakat sehingga dapat meraih berbagai kejuaraan. Dari hasil observasi, hal ini dipengaruhi oleh penggunaan metode faber dalam pembelajaran. Penelitian ini bertujuan untuk mendeskripsikan pembelajaran metode faber di Sekolah Musik Purwacaraka Purwokerto. Pendekatan penelitian yang diterapkan dalam penelitian ini adalah deskriptif kualitatif. Teknik pengumpulan data dilakukan dengan cara observasi, wawancara dan studi dokumen.

Hasil dari penelitian ini menunjukkan bahwa penggunaan metode faber dalam pembelajaran piano klasik di Sekolah Musik Purwacaraka Purwokerto hanya digunakan pada tingkat pemula (Grade Preparatory) dan merupakan metode yang sangat baik untuk pembelajaran pada tingkat pemula karena menggunakan buku- buku yang dirancang khusus bagi pemula dengan banyak memunculkan gambar- gambar berwarna yang membuat siswa berimajinasi, sehingga siswa memahami materi pembelajaran dengan cara mereka sendiri. Kelebihan dari metode faber yaitu peserta didik mendapatkan dasar yang kuat dalam membaca notasi balok, permainan dinamika dan artikulasi dalam sebuah partitur lagu yang dimainkan dan metode ini merupakan metode yang sangat bagus digunakan sebagai dasar belajar piano karena memiliki materi dan teori yang ditekankan untuk memberikan acuan dasar permainan piano dengan teknik bermain piano

Abstract

Purwacaraka Purwokerto Music School is able to give birth to talented classical piano students so they can win various championships. From the observations, this is influenced by the use of the faber method in learning. This study aims to describe learning methods faber at Purwacaraka Purwokerto Music School. The research approach applied in this study is descriptive qualitative. Data collection techniques are carried out by observation, interview and document study. The results of this study indicate that the use of the faber method in classical piano learning in Purwacaraka Purwokerto Music School is only used at the beginner level (Grade Preparatory) and is an excellent method for learning at the beginner level because it uses books specifically designed for beginners with many bring up colorful images that make students imagine, so students understand learning material in their own way. The advantages of the faber method are that students get a strong foundation in reading beam notation, dynamics games and articulation in a score of songs played and this method is a very good method used as a basis for learning piano because it has material and theory that is emphasized to provide basic reference piano playing with piano playing techniques.
\end{abstract}

(C) 2020 Universitas Negeri Semarang ISSN 2503-2850

( Dusic Education, UNNES

postcode 50229

Email : 1. putami69@gmail.com 


\section{INTRODUCING}

Art education is a strategy of implanting knowledge and skills, by adopting students to be creative, innovative, and able to identify their own potential and to have a sensitivity to various cultural and environmental social changes (Surono, 2001:3), (Wafa, 2016). According to (Joseph, 2003: 1) art education is the use of art media to change learners' conduct. Art education mesh with personal education, in links so that the overall educational paradigm includes music education (Winanta, 2018: 18). Art education is expected to be part of the creation of a whole human being (Suharto, 2012:87).

Formal education is education held in schools in general. Formal education is a systematic activity, multilevel, starting from elementary school to college, including in it is a study activity academic and general oriented, programs specialization, and professional training, carried out in a continuous time continuously (Coombs, 1973: 11).

And the concept of informal education is the family and ward educational path. Education was conducted by exemplary, building volitions, and developing learners' creativity in the learning process (statute no. 202003 chapter 1 verse (13).

Non-formal education is any organized and systematic activity outside the school system that is carried out independently or is an important part of broader activities that are intentionally carried out to serve certain students in achieving their learning goals (Coombs 1973). The purpose of non-formal education is to be able to grow and develop to improve the dignity and quality of life, meet the learning needs that are not met in school. There is also a non-formal education unit, one of which is a course.

The development of music education in Indonesia shows considerable progress. Is evident by the large numbers of both formal and non-formal music institutions that have sprung up in Indonesia. The Indonesian people's positive response to the meaning of music education has been a major influence in establishing a music society. Music can be used as an approach choice in helping individuals with physical, behavioral and psychological barriers to better health (Goddess, 2009:108). Therefore, this community's mindset needs to be adjusted in a positive way by the institutions-both formal and nonformal music institutions, by developing both high-quality and directional methods of music learning, so that the objective of music education can be achieved.

One of the institutions of music is the Purwacaraka School of Music. A music school located on Pramuka Street no. 240 South Purwokerto. There are several classes opened in musical instrument learning by the purwacaraka purwokerto music school: vowels, classical pianos, pop pianos, violin, keyboards, drums, and guitars. Based on observations at the purwacaraka purwokerto music school, piano lessons dominate the number of students at the purwacaraka purwokerto music school compared with the other music school in purwokerto because of the curriculum used in the faber classical piano study. The use of the faber method is a particularly appropriate method for a beginner class because the book used in piano studies use modern faber books such as "lesson book level 1" and "perfomance book level 1" in which there are symbols for explanations and piano playing.

In teacher creativity, the faber method is so important to make it easier and seek out the potential of the student that using these symbols children can explore ideas and creativity, and it is hoped that in the short term that such creativity will be the composition that results. It also includes attraction in addition to the use of the faber method of innovation retention.

Maximum achievement of a student in a music school is inseparable from several inhibiting factors such as the material is so difficult that it is not in accordance with one's own abilities, learning that occurs in class is not in accordance with the curriculum so that an evaluation is carried out to correct these deficiencies. In general there are three evaluation functions, namely to: (1) measure progress, (2) support the 
preparation of plans, and (3) make improvements (Sudijono 1996: 7).

Based on the research above, piano learning in each music school uses different methods. Therefore, researchers are interested in conducting research at the Purwacaraka Music School Purwokerto which uses the faber method in classical piano learning. The formulation of the problem in this research is how to use the faber method in classical piano learning at Purwacaraka Purwokerto Music School and how is the constraint of using the faber method in classical piano learning at Purwacaraka Music School Purwokerto.

\section{METHOD}

This research is a study using qualitative descriptive methods, because researchers analyze data objectively based on facts and then the results of the study are presented in descriptive form containing the use of the faber method in classical piano learning as well as the constraints in using the faber method at the Purwacaraka Music School Purwokerto.

The data-collecting techniques that researchers use are library studies, observations, interviews and document studies. Library studies are done by researchers studying related writing to supplement their insights. Researchers conducted observation over a period of two months.

The primary sources in the study are classic piano teachers, classical piano student grade preparatory, and the parents of classical piano students. Sources are chosen because they are directly involved in the subject being studied. Then the researcher also obtained data from a study of the document consisting of notes relating to classical piano study at the Purwacaraka Music School Purwokerto.

\section{RESULT AND DISCUSSION Purwacaraka Music School Purwokerto} Purwacaraka Music School Purwokerto was established on March 13, 2010 and was inaugurated directly by $\mathrm{Mr}$. Purwacaraka and attended directly by the leadership, employees and teaching staff of the Purwacaraka Music School
Purwokerto. This music school is a branch of Purwacaraka Music Studio center owned by Mr. Purwacaraka.

When it was inaugurated, Purwacaraka Music School Purwokerto immediately opened several classes of instruments namely piano, keyboard, violin, guitar, vocals, and drums which have survived until now. Two years running precisely in 2012 Purwacaraka Music School Purwokerto held a Big Concert held at Moro Square and featured several ensembles such as violin ensembles, guitars and bands played by students. The following year, precisely in 2013, the Big Concert was held again at the same location, Moro Square, and featured more ensembles such as piano, violin, guitar, and big band ensembles, as well as some performance offerings from the teacher at Purwacaraka Music School Purwokerto.

There are 13 teaching staff at Purwacaraka Music School Purwokerto, consisting of 2 piano teachers, 2 keyboard teachers (1 teacher who teached 2 instruments), 2 guitar teachers, 2 violin teachers, 4 vocal teachers, and 2 drum teachers. All teachers are music academics from UNNES (Semarang State University), UNY (Yogyakarta State University), UPI (University of Indonesian Education), and ISI (Indonesian Institute of the Art) Yogyakarta.

During the 8 years of the establishment of Purwacaraka Music School Purwokerto, there was a change in the number of students, some entering and leaving. The number of students in the Purwacaraka Music School in 2018 is numbered 188 people. The number of students is divided into several classes, namely classical piano, piano pop, keyboard, guitar, violin, vocal, and drum classes. Students enrolled at the Purwacaraka Music School Purwokerto come from various levels of education and some even work.

\section{Classical Piano Learning Curriculum}

Purwacaraka Music School

Purwokerto uses a curriculum created with innovative teaching techniques. Developed carefully and internally by a team of educators, and uses many reference sources 
from 8 years of teaching experience in educating music.

Books are an important role in the learning process. In addition to music books available on the market, Purwacaraka Music School Purwokerto also publishes music education books for use in classrooms and student training at home. The curriculum team at Purwacaraka Music School Purwokerto presents colorful books for children to attract students' interest and imagination while learning so they can create a fun learning experience.

In classical piano learning at Purwacaraka Music School Purwokerto there are 8 levels or grades, but for the implementation of classical piano learning only up to Grade III. Participants educated in Grade I to Grade III must first pass the classical piano learning level to beginners (Preparatory) and also must pass the level examination. The following will explain the classical piano learning curriculum at each level or grade.

Beginner level or Grade Preparatory is the most basic level in learning classical piano. Classical piano learning at the beginners level are with the faber method. The use of the faber method has been determined according to the applicable curriculum at Purwacaraka Music School Purwokerto because the faber method is more modern than other methods normally used in classical piano learning, it is evident that some students who take classical piano learning with the faber method understand the material as well as the spirit of participating in learning classical piano level beginner because the books that are used there are many colored pictures. At this level there are 2 material that will provide, practice and theory.

The beginner level (Grade Preparatory) in the Purwacaraka Music School Purwokerto is divided into two namely the beginner level A (Grade Preparatory A) and the beginner level B (Grade Preparatory B). Explanation of material in piano learning books that are used for the beginner level (Grade Preparatory), namely explaining the basic material specifically designed for beginners with a variety of pictures and symbols about explanations in piano play.

Level (grade) 1 is an advanced stage of the basic level, because students can continue the material at level 1 after they take the material at the basic level. Outline of learning material at level 1 there are two namely Repertory Grade $1 \mathrm{~A}$ and Repertory Grade $1 \mathrm{~B}$. The learning book used between Repertory Grade 1 A and Repertory Grade $1 \mathrm{~B}$ is the same, only different in the selected material book.

Level (grade) 2 is an advanced stage of level 1 , because students can continue the material at level 2 after they take the material at level 1.

The outline of learning material at level 3 is using piano learning books such as (1) Graded Pianoforte Studies Grade 3 (1st series), (2) Graded Pianoforte Studies Grade 3 (2nd series), (3) First Lesson Bach - Book 2, and (4) A Romantic Sketchbook For Piano - Book 2.

All classical piano students get the learning books at the level of each student. The book used to study during class with a classical piano teacher at Purwacaraka Music School purwokerto and to study at home.

\section{The Faber Method in Classical Piano Learning}

Classical piano learning at the Purwacaraka Music School Purwokerto by using the faber method aims to create a strong musical understanding and playful, imaginative, and structured play technique to create a strong foundation in playing piano, said Anis as a classical piano teacher at Purwacaraka Music School Purwokerto. Classical piano learning at the school uses a private system where each learning in the classroom there is only one student taught by one classical piano teacher so that each student has a different schedule.

The faber method is a piano learning method created by Nancy and Randall Faber. The faber method is only applied to beginner classical piano learning (Preparatory). The beginner level (Preparatory) in classical piano learning at Purwacaraka Music School Purwokerto is divided into two namely the beginner level 
A (Preparatory A) and the beginner level B (Preparatory B).

Classical piano learning at the Purwacaraka Music School Purwokerto is held every day, except for National Holidays with a duration of 45 minutes at each meeting. In the classical piano learning process, Mrs. Anis and Mr. Damar as piano instructors are provided with guidelines covering, (1) learning material, (2) learning methods, (3) learning stages, and (4) learning evaluation. These four guidelines are components in classical piano learning at Purwacaraka Purwokerto Schools that must be considered so that the objectives of classical piano learning can be achieved.

Furthermore, the elaboration on learning materials, learning methods, stages of learning and evaluation of classical piano learning in Purwacaraka Music School Purwokerto will be explained in more detail.

1. Material in the Faber Method

The material used in classical piano learning at Purwacaraka Music School Purwokerto is adjusted to the curriculum applied at the music school. The material here is divided into two, namely music theory material to support knowledge about learning music, especially classical piano and practice material whose contents are choices of song repertoires that are adjusted to their level.

Material for practice theory is used as a basic theory in classical piano learning at Purwacaraka School of Music Purwokerto, practical theory includes (1) $G$ and $F$ keys, (2) notation in $G$ and $F$ keys, (3) form and value notation, (4) signs bar, (5) rest, (6) simple music terms. While the material used for practice in Grade Prepatory is about (1) basic techniques: sitting position, hand and finger shape, (2) use of $G, F$ keys and notation in each key, (3) technical training using 5 fingers in legato play, (4) melody and accompaniment exercises, (5) hand coordination exercises: both hands must play tones together, (6) staccato, pharsing and simple dynamics exercises, (7) exercises using fingers or fingering differ in the same notation, (8) variations of children's songs especially for young children, (9) sight reading, (10) aural garde preparatory.

At the beginner level (Prepatory) the material for practical theory is about (1) the structure of the major minor scales, (2) the structure of arpeggios in the major and minor book scales used for classical piano learning that uses the book "Lesson Book Primer Level" and " Primary Book Performance Level ". Next is the description of the block notation that is explained for playing the right hand and left hand when playing the piano.

2. The Faber Method for Levels Preparatory

Class Preparatory classical piano learning method implemented at the Purwacaraka Music School Purwokerto is to use the faber method which is arranged according to the curriculum set by the Central Purwacaraka Music School. In its application, classical piano teacher always prioritizes the quality of learning by following the instructions or learning paths listed in the book and interspersed with stories about the material in the Class Preparatory classical piano learning book, so that students can easily understand the material presented by a classical piano teacher. The advantages of using the Faber method in learning classical piano Preparatory Grade is that students get a strong basis in reading the notation of the beam, dynamic play and other articulations in a song sheet that is played and this method is a very good method used as a basis for learning piano because it has material and theories emphasized to provide basic reference piano play.

This is evidenced by students who continue piano learning at the next level can follow the learning quickly, students are already fluently applying fingers in the correct position when reading sheet music when studying in class and also playing with dynamics in accordance with sheet music without having to practice repeatedly.

(a) Learning Process 
Communication always occurs between the teacher and the students. Teachers and students are the main elements in a learning that occurs in the classroom. At Purwacaraka Music School Purwokerto, Anis as a piano teacher always has a strategy to give lessons that make students comfortable to take piano lessons. The following will explain how the classical piano learning process by Ms. Anis at Purwacaraka Purwokerto Music School

The initial stage before starting learning, Ms. Anis always prepares students to be focused and ready to follow the learning in a way, she plays a few songs from selected material at the previous meeting (for all students) and coloring the pictures contained in the special learning book for beginner level ( Preparatory Grade). Then after playing the piano, he invited to talk about the pictures in the learning book and explain a little about the learning material.

The next stage students begin to play the piano in accordance with the techniques and materials taught at that moment. At this stage students begin to imagine about the learning material being played, so students quickly understand the material taught by their teacher.

The last stage the teacher always asks whether the student understands the material being taught or not. If student does not understand the material being taught, she always repeats the part that is not understood by students and repeated slowly until the student really understands the material being taught.

(b) Explaining Technique

According to Trisakti (in Sayekti, 2017: 14), success in the learning process is a major factor that depends on the knowledge and skills of teachers in carrying out learning, such as explaining techniques during learning. The technique explains the same as the learning model which is a framework of thought to direct a teacher to design, implement, and guide so that there is a more directed teaching and learning interaction (Karli in Pandapotan, 2018: 8). The explaining technique that was carried out by Ms. Anis as a classical piano teacher at the Purwacaraka Music School in Purwokerto was a very efficient technique. One of them at the beginner level learning (Grade Preparatory). Before entering learning material, Ms. Anis always tells learning material in a storytelling way so that students always imagine about the fairy tale which is then applied in the learning material.

3. Stages of Learning Methods Faber for Preparatory Level A Beginner level classical piano learning A (Grade Preparatory A) at the Purwacaraka Music School Purwokerto is carried out in stages, the aim being that students can understand in detail all the material taught by the classical piano teacher at each meeting. The stages in learning classical piano beginner level A (Preparatory Grade A) will be explained below.

(a) Introduction to Black Keys

In the introduction of black keys, students are trained by using 2 fingers first, finger 2 and finger 3 on the left and right hand. Then 3 fingers, finger 2 , finger 3 and finger 4 on the left and right hand. The introduction of black keys is intended so that students can balance the piano playing by using the left hand and right hand especially on the black keys which are often ignored. Then so students can know that black keys are also important in playing piano because in general students assume that black keys are decoration on the piano and are difficult to play, so students only use white keys because they are considered easy to play. The introduction of black keys is held at second to third meeting.

(b) Introduction to Notation Beat

The introduction of notation beats aims to make students understand about the beat of notation when playing sheet music and to strengthen fingers when playing the piano, especially the weak left hand to press the piano keys. The teacher will give an understanding of the beat notation by describing that "music 
like our body that has a stable heartbeat", in this case the teacher gives the understanding that the rhythm of a song can change, can be slow, medium or fast but must be stable.

Then the teacher will instruct students to practice beats by hand. After students understand, the teacher tells students to play on the piano, students are free to choose which notes they want to play. At this stage the teacher starts using a metronome, this aims to keep students stable in playing the beat of notation.

The next stage students begin to play the song with $1 / 4$ notation so that students understand more.

The notation beat introduction material is held at 4-6 meeting.

(c) Introduction of Dynamics Signs Dynamics sign is a sign that is used to show the softness of the sound issued. The introduction of the dynamics sign aims to make students understand where to play the piano aloud or soft sound so that the song being played sounds good. Material for the introduction of dynamic signs was held at the 7-8 meeting.

(d) Introduction of the name of the notation

The introduction of the name of the notation at this stage is only on the white keys, it is intended that students understand the names of the notations, and can distinguish groups of black keys between white keys. The introduction of the name of the notation also aims to make students know about the high and low notes, so students understand the meaning of playing the piano position low (low), middle (middle), and high (high). This material also aims at piano fingering techniques to emphasize students the appropriateness of sounding tones with fingering in the emphasis of piano keys (Rusdewanti, 2014: 5). Introduction material of name notation was held at 912 meeting.

4. Evaluation of Classical Piano Learning
Evaluations carried out in classical piano learning at the Purwacaraka Music School Purwokerto is held every three months and an annual grade examination is held once in January. This evaluation is to test the readiness of students in facing the next grade, knowing the safety of students in the previous grade material.

Evaluation tests are conducted every 3 months in the classroom when learning by the piano teacher, while the assessment of practice is carried out when the Purwacaraka Music School holds a "Home Concert". The material being tested is song, sight reading, fingering, aural test, attendance, and finally the practice process at home or in class.

While the grade promotion test for the beginner level (Grade Prepatory), the material being tested is the sitting position, the shape of the hands and fingers, basic techniques include articulation and two hands, counting, aural test including applause and reading notation. For grade upgrading tests held every January, the material tested in the form of scales, pieces A, pieces B, pieces $\mathrm{C}$, sight reading, and aural tests are tested directly by examiners from the center. Students who have passed the grade promotion exam will receive a certificate. Evaluation is carried out to determine student development during classical piano learning at the Purwacaraka Music School Purwokerto.

5. Constraints on Using the Faber Method

Faber methods in Classical Piano Learning at the Purwacaraka Music School Purwokerto there are no obstacles, but in the process there are two obstacles that hinder students' development in learning piano. The obstacles are (1) Students are less interested in learning the piano because they entered piano class at the Purwacerto Purwokerto Music School forced by their parents to play the piano. (2) There are some students who do not have a personal piano at home so that it is 
not possible to study daily material and test material at home.

To overcome these obstacles, Anis as a classical piano teacher at Purwacaraka School of Music Purwokerto always communicates with parents discussing developments during piano learning as well as obstacles that become a hindrance in the learning process of classical piano. The obstacles of students' lack of interest in learning classical piano because they were forced by their parents can be overcome by being included in the concert, thus the enthusiasm of students will emerge and feel responsible for the material that will be presented at the concert. The student will study hard so the results don't disappoint.

Then the obstacles of students who do not have a private piano at home can be overcome by the way the student is exercised in the classroom before learning begins. To face the exams these students can rent piano classrooms so they can study and when studying with classical piano teachers, half the time of the learning schedule is used to practice the exam material so that when the exam is carried out these students can follow it well.

The obstacles that occur in the use of the Faber method in learning classical piano occur in students aged 7 years and below, namely some students when tested to play sheet music that has never been played before students are not fluent to play the song, but to read the song notation has been smoothly. So it can be concluded that the learning of classical piano with the faber method in students under the age of 7 must be emphasized again the basics in playing the piano, especially in the days learned in the introduction of black and white keys, recognition of the location of the notes on the piano keys, and the sitting position.

\section{CONCLUSION}

Based on the results of research and discussion on the use of the faber method in learning classical piano at the Purwacaraka Music School Purwokerto, it can be concluded that:

Faber method is a method that is arranged according to the curriculum at Purwacaraka Music School Purwokerto. The use of the faber method in classical piano learning is only applied at the beginner level (Grade Preparatory) which is divided into Grade Preparatory A and Grade Preparatory B. Material at the beginner level (Grade Preparatory) is divided into two namely practical theory material and practice material. The learning book used for classical piano learning is by using faber books that are already modern and specifically designed for beginners with lots of pictures, so students are interested in learning the material in faber books.

The classical piano learning process, the teacher is provided with guidelines namely (1) learning material, (2) learning methods, (3) stages of learning, and (4) evaluation of learning. The guideline is a component of classical piano learning at Purwacaraka Music School Purwokerto.

Before starting learning, the teacher reviews the learning material in a way to tell students to focus on learning classical piano. Then after the students focus, the teacher invites students to color the pictures in the learning book in accordance with the wishes of the students. After coloring, the teacher starts to explain the material and invites students to practice the learning material that has been discussed.

The obstacles that occur in the use of the Faber method in learning classical piano occur in students aged 7 years and below, namely some students when tested to play sheet music that has never been played before students are not fluent to play the song, but to read the song notation has been smoothly. So it can be concluded that the learning of classical piano with the faber method in students under the age of 7 should be emphasized again the basics in playing piano, especially in the learning of material on the introduction of black and white keys, introduction to the location of notes on the piano keys, and sit position. 
Evaluation of classical piano learning at Purwacaraka Purwokerto Music School by using the faber method is carried out every year for grade-ups and monthly assignment evaluations aimed at measuring students' abilities in terms of strong musical understanding and correct playing techniques and testing students readiness in facing the next grade. The students' abilities to be tested include: (1) sitting position, (2) hand and finger shape, (3) basic techniques (articulation: legato, staccato and two hands), (4) counting, (5) sight reading, and (6) aural test includes applause and note reading. From the aspects tested, almost all students were able to pass it very well and smoothly. Students who take the graduation exam pass around $90 \%$.

In connection with the results of their learning, students proved to be happy and able to play songs using a piano instrument with the right playing techniques, students were also able to read song notation and punctuation well. Thus, the application of the Faber method in classical piano learning is proven effective for learning at the elementary level, because it can be used as a strong foundation or foundation in classical piano playing with good and correct techniques and effective ways to foster musical sensitivity and skills of students.

\section{REFERENCE}

Coombs. 1973. New Path to Learning. New York: International Council for Education Development.

Depdiknas. 2003. Undang-undang RI No.20 tahun 2003 tentang sistem pendidikan nasional. Jakarta: Balai Pustaka.

Dewi, Mahargyantari P. 2009. "Studi Metaanalis: Musik Untuk Menurunkan Stres". Jurnal Psikologi. Desember. Volume 36. Nomor 2. Hlm. 106-115. Depok: Universitas Gunadarma.

Joseph, W. 2003. "Pendidikan Kesenian di Sekolah Sub Materi Musik". Jurnal Harmonia, April. Volume 4. Nomor 1.
Hlm. 1-9. Semarang: Universitas Negeri Semarang.

Pandapotan, Dwiyan. 2018. "Metode Pembelajaran Piano Untuk Anak Usia 3-5 Tahun Di Yamaha Music School". Jurnal Pendidikan Sendratasik, Volume 6. Nomor 1. Hlm. 1-18. Surabaya: Universitas Negeri Surabaya.

Sayekti, Dinda C. 2017. "Pembelajaran Piano Beginner Grade 1-2 Program Private Class Di Sekolah Musik Indonesia Cabang Rungkut Surabaya". Jurnal Pendidikan Sendratasik, Desember. Volume 6. Nomor 1. Hlm. 1-16. Surabaya: Universitas Negeri Surabaya.

Sudijono, Anas. 1996. Pengantar Statistik Pendidikan. Yogyakarta: PT Raja Grafindo Persada.

Suharto. 2012. "Problem in Implementation of Arts Education in Non- Arts Vocational Schools". Jurnal Harmonia: Journal of Arts Research and Education, Volume 12. Nomor 1. Hlm. 87-94. Semarang: Universitas Negeri Semarang.

Surono, C. K. (2001). Konsep Pendidikan Seni Tingkat SD-SLTP-SMU. Jakarta: Jakarta.

Rusdewanti, Panca P. 2014. "Upaya Peningkatan Hasil Belajar Piano 2 Melalui Metode Sight Reading Di Jurusan Pendidikan Seni Musik FBS UNY". Jurnal Pendidikan Seni Musik. Volume 13. Nomor 2. Hlm. 117. Yogyakarta: Universitas Negeri Yogyakarta.

Wafa, Mochammad Usman. (2016). Implementasi Konsep Ekspresi dan Kreasi dalam Pembelajaran Seni Musik di SMP Karangturi Semarang. Jurnal Seni Musik 5(1).

https://doi.org/10.15294/jsm.v5i1.18400

Winata, D. A. 2015. "Pembelajaran Piano Klasik untuk Siswa Tingkat Dasar di Maestro 
Nur Aini Putri Utami / Jurnal Seni Musik (9) (1)

Music School Semarang". Skripsi. Semarang:

FBS UNNES. 